\title{
Remittances and Institutions: Are Remittances a Curse?
}

\author{
Yasser Abdih* \\ International Monetary Fund \\ $70019^{\text {th }}$ Street, N.W. \\ Washington, D.C. 20431 \\ Phone: (202) 623-7442 \\ E-Mail: yabdih@imf.org
}

\author{
Ralph Chami \\ International Monetary Fund \\ $70019^{\text {th }}$ Street, N.W. \\ Washington, D.C. 20431 \\ Phone: (202) 623-6039 \\ E-Mail: rchami@imf.org
}

\author{
Jihad Dagher \\ University of Southern California \\ Department of Economics, KAP 300 \\ 3620 S. Vermont Ave. \\ Los Angeles, CA 90007 \\ Phone: (213) 235-5305 \\ E-Mail: dagher@usc.edu
}

\author{
Peter Montiel (Corresponding author) \\ Williams College \\ Department of Economics \\ Williamstown, MA 01267 \\ Phone: (413) 587-2103 \\ E-Mail: Peter.J.Montiel@williams.edu
}

*The authors would like to thank Leslie Lipschitz, Tom Cosimano, Andrew Feltenstein, Connel Fullenkamp, and Mike Gapen, for valuable comments and suggestions. The authors also would like to thank Ms. Asmahan Bedri and Ms. Yasmina Zinbi for help in editing and formatting the paper. 


\title{
Remittances and Institutions: Are Remittances a Curse?
}

July 2010

\begin{abstract}
This paper addresses the complex and overlooked relationship between the receipt of workers' remittances and institutional quality in the recipient country. Using a simple model, we show how an increase in remittance inflows can lead to deterioration of institutional quality - specifically, to an increase in the share of funds diverted by the government for its own purposes. In a cross section of 111 countries we empirically verify this proposition and find that a higher ratio of remittances to GDP leads to lower indices of control of corruption, government effectiveness, and rule of law, even after controlling for potential reverse causality.
\end{abstract}

JEL Classification Numbers:D02, D64, F02, F22, F24

Keywords: Remittances, Institutions, Corruption 


\section{INTRODUCTION}

Inflows of workers' remittances have been growing rapidly in many developing countries at least since the early 1990s. With recent estimates putting remittances at $\$ 135$ billion, they now rival and even exceed other types of balance of payments inflows that have traditionally received much more attention. Since 1998, these private income transfers-at least those flowing through official channels-have been second only to FDI flows, but several times larger than remaining private capital inflows and official aid (World Bank (2006), IMF 2005, and Chami et al. 2008).

There is now a substantial literature that documents the welfare-enhancing benefits of remittances for the recipients. For example, remittances are credited with reducing poverty, and their compensatory nature is responsible for minimizing consumption volatility of transfer recipients (See, for example, Chami, Fullenkamp, and Jahjah (2003), World Bank (2006), IMF (2005), among others). Researchers, however, have also recognized that these flows entail several development challenges, specifically in terms of their effect on growth [see, for example, Chami et al. (2003), World Bank (2006), and IMF (2005)], and Dutch disease effect [see for example, Acosta, Lartey and Mandelman (2007), among others].

In contrast to the well documented impact of remittances on recipient households, the macroeconomic impact of these flows has received scant attention. Recently, however, Chami, Cosimano and Gapen (2006) show that remittances also affect fiscal policy in the recipient countries. For example, by increasing the revenue base, remittances reduce the marginal cost to the household of government distortionary policy. Conversely, for a given level of distortion, remittances allow the government to carry more debt or incur more 
expenditures. These flows, therefore, have similar budgetary implications and incentive effects on government behavior as do natural resources such as oil.

This latter effect of such windfalls on government behavior was highlighted recently by Sala-i-Martin and Subramanian (2003), who show that the natural resource curse can lead to lower long-term growth for countries with oil and minerals. According to them, these windfalls may increase reduce the quality of institutions and governance in these countries, with adverse effects on growth. The revenue from oil and minerals plays a buffer role between government and citizens: because the government can substitute these windfalls for taxes to finance a larger and less efficient public sector, the incentive for citizens to monitor and hold the government accountable are reduced. As a result, rent-seeking and corruption increase, reducing the quantity and quality of investment. Sala-i-Martin and Subramanian go on to argue that by disbursing the revenue from these resources among the people, the adverse incentive effect on government behavior may be mitigated.

In this paper, we test whether remittance flows, by also acting as a buffer between government and the people, impact the quality of institutions in countries that receive these flows. To our knowledge, this is the first such exercise measuring the impact of remittance flows on government behavior. At first glance, one might ask why these private income transfers should impact government policy, especially given that these flows are not taxed and, as a result, not mediated by the recipient-country government. Instead, they are household-to-household non-market private income transfers, widely dispersed, and usually allocated in small amounts. So one might expect [as is argued in World Bank (2006)] that remittances may escape or avoid the adverse effects of oil windfalls on institutional quality. 
We show, however, that the presence of these flows will nevertheless affect the incentives faced by the government, and may therefore have important impacts on the quality of domestic governance. We focus specifically on the government's incentives to divert resources for its own use, which we will label generically as "corruption." Remittances inflows may affect these incentives through either or both of two channels. First, even when remittances are not taxed directly, their presence expands the base for other taxes (e.g., the VAT), thereby making it less costly for the government to appropriate resources for its own purposes. Second, the nontaxable exogenous resources that remittances provide for households makes it possible for them to finance the purchase of goods that may substitute for public services. In that case, access to remittance income makes government corruption less costly for domestic households to bear, and consequently such corruption is likely to increase.

In Section 2, we construct a simple model illustrating these points. These insights motivate our empirical work. In Section 3, we use standard cross-country regressions to explore the effects of remittance inflows on institutional quality in the recipient countries, and conduct several robustness checks. We are well aware that remittances could be endogenous to the presence of corruption, or more broadly to the quality of domestic economic institutions in general, since it is quite plausible that poor domestic governance could lead to larger emigration, which itself could lead to increased remittances. We attempt to isolate the causality from remittances to corruption through an instrumental variable approach. Our results point to a negative and robust impact of remittances on the quality of governance in countries that receive these flows. In Section 4 we conclude, however, that the prescription 
advocated for resolving the dilemma of the impact of revenue from oil and minerals on government behavior - that is by disbursing the revenue from such windfalls—-does not transfer to the case of remittances, which are already disbursed in this manner. Instead, we offer alternative policy advice for countries that rely on these flows.

\section{A Simple Model: Public Good Provision in The Presence of Non-Taxable REMITTANCES}

We begin by developing a simple model that outlines a plausible channel through which the presence of non-taxable private income transfers to households, such as remittances, can affect the quality of domestic governance. We use the term "government effectiveness" in this model to refer to the extent to which resources are devoted to increasing the welfare of a representative agent, rather than diverted for other purposes such as furthering the wellbeing of the public-sector decision-maker. Thus, the notion of effectiveness captured in our model most naturally corresponds to government corruption.

We assume that households choose consumption to maximize their utility, while an intrinsically non-benevolent government is interested in both its (financial) welfare as well as that of the household. ${ }^{1}$ For simplicity, the model has only 2 goods. One is a private good that must be purchased by the household, and the other a good that could be provided by the government or purchased by the household. The source of funding for the latter, which we will refer to for simplicity as the "public service," does not affect the marginal utility derived

\footnotetext{
${ }^{1}$ Presumably the government would not be able to maintain political power if it did not care to some degree about the wellbeing of households.
} 
from its consumption. That is, whether provided by the government or by the household, the good is of the same quality. The intention is to capture the fact that many of the services that are provided by the public sector in recipient countries can also be acquired privately. For example, households can decide to buy education and health care services or even security services on their own if the public provision of these services is non-existent or is of poor quality. ${ }^{2}$ In general, given the assumed uniformity of quality, households would prefer for the government to provide the public service as long as the increase in taxes due to this provision does not offset the benefit they derive from these goods. For simplicity we assume initially that the tax rate is independent of the provision of the public service by the government. Our objective is to show in this simple framework that an increase in these nontaxable private income transfers from abroad to households in the country of origin can impact the provision of public services.

\section{A. The Representative Agent Problem}

Households care about their consumption of the private good as well as the public service.

They take the government provision of the latter to be exogenous, and choose their own consumption of the two types of goods, $c$ and $g$, to maximize:

\footnotetext{
${ }^{2}$ Households in many developing countries that receive remittances use these private income transfers to purchase goods and services (from private suppliers) that are usually provided by the public sector [see, for example, Roth (1987)]. An example of this substitution between publicly and privately funded services-can be seen with the recent rise in the hometown associations (HTA), which became very common in particular in Latin America. These philanthropic organizations, comprised of emigrants from a particular country, generally provide financial assistance to their communities in that country, by pooling the transfers among them, and using them to finance projects back home. For example, HTAs are often involved in providing support to public infrastructure activities such as construction of roads, schools and health facilities. In many cases, however, their contributions dwarf that of the public works budget in their countries of origin (see for example, Mexican HTA, in Orozco and Lapointe 2003).
} 


$$
U(c, g, \bar{g})=\alpha \log (c)+(1-\alpha) \log (g+\bar{g})
$$

where $c$ is the agent's consumption of the private good, and $g$ is the agent's consumption of a good that is a perfect substitute for the public good, while $\bar{g}$ is the level of government provision of the public good. The agent's budget constraint is the following:

$$
(1-t) y+R=c+g
$$

Where $y$ is the agent's income, $t$ the tax rate, and $R$ (which stands for remittances) represents the foreign non-taxable private income transfers received from abroad. The assumption that remittances are non-taxed accords with the general situation in recipient countries [see, for example, World Bank (2006), among others].

Maximizing (1) subject to (2) yields:

$$
g^{*}=(1-\alpha)[(1-t) y+R]-\alpha \bar{g}
$$

Therefore, taking the level of government provision of the public good as given, private purchases of the public good are increasing in household disposable income (domestic and foreign) and decreasing in the government's provision of the good. This result is intuitive: when households prefer to keep relatively constant the share of a good in their consumption 
basket, a higher endowment of a certain good $(\bar{g})$ will decrease the demand for this good $(\mathrm{g})$, everything else equal, and increase consumption of the other goods $(c)$.

\section{B. The Government's Problem}

One central assumption in this model is that the government does not behave like a central planner. In particular, suppose that the government cares about maximizing a combination of the representative agent's utility and its own utility, derived from resources that the government reserves for itself. In that case the government's problem consists of maximizing:

$$
\Psi(\bar{g}, U)=\beta \log (s)+(1-\beta) U(c, g, \bar{g})
$$

where $s$ stands for whatever the government keeps for its own consumption. The government chooses how much of the resources that it collects to divert for its own purposes. It therefore chooses $\bar{g}$ to maximize (4) subject to the budget constraint: ${ }^{3}$

$$
t y=\bar{g}+s
$$

\footnotetext{
${ }^{3}$ The assumption that government chooses spending while holding revenue constant is more realistic than the alternative, because taxes tend not to be as volatile in general as government spending (see Poterba and Rotemberg 1990). However, this assumption is without loss of generality. Since tax revenues and spending enter equation (6) below only in the form $t y-g$, our conclusions would be unaffected if we made the alternative assumption.
} 
As mentioned earlier, remittances are not taxed, and we do assume that the government does not change the tax rate. Later on we will consider what happens when this assumption is relaxed.

\section{Stackelberg Game}

Since the government knows the problem of the representative agent and therefore the reaction of private agents to its own spending decisions, it will take this reaction into account in its optimization problem. However, since it is highly unlikely that private agents could cooperate so as to be able to play a Nash bargaining game with the government, it is most natural to assume that individual private agents take the government's provision of the public good as fixed and unaffected by their actions. ${ }^{4}$ Therefore we assume that our model economy works as a Stackelberg game where the government moves first. Under this assumption, and replacing (3) and (2) in the objective function of the government yields the following:

$\Psi(\bar{g})=\beta \log (t y-\bar{g})+(1-\beta)\{\alpha \log [\alpha((1-t) y+R+\bar{g})]+(1-\alpha) \log [(1-\alpha)((1-t) y+R+\bar{g})]\}$, which simplifies to:

$$
\Psi(\bar{g})=\beta \log (t y-\bar{g})+(1-\beta)[\alpha \log (\alpha)+(1-\alpha) \log (1-\alpha)+\log ((1-t) y+R+\bar{g})]
$$

\footnotetext{
${ }^{4}$ For example, if all agents decreased their private consumption of the public good they might be able to force the government to increase its own spending; however such an assumption would obviously be unrealistic.
} 
When $\Psi(\bar{g})$ is maximized with respect to $\bar{g}$ it yields:

$$
\bar{g} *=(t-\beta) y-\beta R
$$

Equation (7) simply says that the public provision of the public good is increasing in the tax base, $y$, but decreasing in the amount of (non-taxed) remittances. ${ }^{5}$ The substitutability between private and public provision of the good $g$, however, implies that an increase in the tax base y does not fully translate into an increase in the provision of the public good $\bar{g}$. Instead, part of that increase in the revenue base, which includes remittances, $\beta(y+R)$, is diverted to the government's own consumption. Given this optimal level of spending on the public good, we can easily derive the optimal level of resources diverted to the government's own consumption:

$$
s^{*}=\beta(y+R)
$$

Note that the amount diverted does not depend on the tax rate, but is increasing in the revenue base, that is, income and remittances. The "fiscal space" provided by the revenue base, and in particular, the remittances, increases the household's private consumption of

\footnotetext{
${ }^{5}$ Since we know it is virtually always the case that government-spending increases with GDP we assume that $t>\beta$, in other words, that there is a threshold level of government self-interest $\bar{\beta}$ such that governments with levels of $\beta$ beyond this threshold are easily ousted from power.
} 
both goods $(c, g)$, which allows the government to free ride and reduce its contribution to the public good, thereby increasing its own consumption.

It is also clear that the government's proclivity to divert resources to its own consumption, measured by $\beta$ leaves the household worse off in equilibrium: replacing (3) and (7) into (1) we have:

$$
\frac{\partial U\left(c^{*}, g^{*}, g^{*}\right)}{\partial \beta}=-\frac{1}{(1-\beta)}<0
$$

We can express the rate of resource diversion as a ratio either to total government spending or to total income. These ratios are given respectively by:

$$
\frac{\overline{s^{*}}}{\overline{g^{*}}}=\frac{\beta y+\beta R}{(t-\beta) y-\beta R}=\frac{\beta\left(1+\frac{R}{y}\right)}{(t-\beta)-\beta \frac{R}{y}}
$$

Field Code Changed

$$
\frac{\bar{s}^{*}}{y}=\beta\left(1+\frac{R}{y}\right)
$$

As one can easily see:

$$
\frac{\partial\left(\overline{s^{*}} / y\right)}{\partial(R / y)}=\beta>0 \text { and } \frac{\partial\left(\overline{s^{*}} / \bar{g}^{*}\right)}{\partial(R / y)}=\frac{\beta t}{[(t-\beta)-\beta(R / y)]^{2}}>0
$$


That is, both measures of corruption are increasing in the level of remittances relative to GDP.

\section{EVIDENCE}

The model in section 2 suggested a channel through which remittances can increase the level of corruption in a country, even though they do not provide a direct source of revenue for the government. We now turn to the data to see if the evidence is consistent with such an effect. We use a cross section of 111 countries, chosen on the basis of the availability of data on workers' remittances. Our remittance variable is measured as the average ratio of worker remittance flows to GDP between 1990 and 2000. It is enough for a country to have one observation on remittances during this period to be in our sample. A detailed description of the data and a listing of data sources are included in Appendix B, Tables 9 and 10.

\section{A. OLS Results}

To ensure that our results can be compared with those in the literature that studies the determinants of government quality, we use the framework of the seminal work by La Porta, Lopez-de-Silanes, Shleifer and Vishny (1999) — henceforth PLSV— and add our own regressors. Our main regression model is therefore the following:

Corruption control $_{2000}=\alpha+\beta_{1} *$ economic $+\beta_{2} *$ religion $+\beta_{3} *$ legal $+\gamma_{1} *$ remittances 
Our endogenous variable is taken from the World Bank governance indicators. It is a measure of control of corruption (inversely related to the degree of corruption) in the year 2000. We regress this measure on average remittance receipts between 1990 and 2000 while controlling for economic, religion, and legal variables, as in PLSV.

As a first step, we ignore all endogeneity issues stemming from the inclusion of a measure of remittances on the right hand side of the regression.

The OLS results are shown in Table 1, Appendix A. In Column (1) we simply regress the index of corruption control (denoted Corrup) on remittance flows. We find a negative and significant coefficient, as suggested by our model. In column (2) we add a measure of energy depletion in the country. Its coefficient turns out to be negative and statistically significant, consistent with the findings of many recent studies that oil-rich countries tend to have worse institutions on average (see Sala-i-Martin and Subramanian (2003) and Leite and Weidmann, (1999)). The coefficient of remittances remains negative and significant. Indeed, this coefficient remains negative in all the specifications we use in this paper. In columns (3) and (4) we add the regressors that La Porta et al. (1999) use in their regressions (Table 9 in Appendix B provides a description of all the regressors used in this paper). We follow their approach by alternating the religion and the legal variables as regressors, since they are correlated. ${ }^{6}$ In column (3) we add the legal variables. Among these, only the dummy for

\footnotetext{
${ }^{6}$ If both sets of variables are combined, the significance of the religious variables drops significantly, while the coefficient on remittances does not change significantly and its t-statistic is -1.64 (significant at the 10 percent level).
} 
Scandinavian laws is positive and significant, which is similar to the result in La Porta et al. (1999). The coefficients on remittances and energy remain negative and significant in this specification as well as in column (4), where we replace the legal variables by variables that measure the prevalence of certain religions in these countries. Similar to La Porta et al. (1999), we find a negative and significant coefficient on both the variables "Muslim" and "Catholic" while the coefficient on "Other Denominations" is negative; however, unlike in La Porta et. al., it is slightly insignificant. Note that the R-squared improves dramatically in columns (3) and (4) when we add the legal or religion variables.

As in PLSV, we add to both specifications real GDP per capita, whose coefficient we find to be positive and strongly significant. This captures the idea that richer countries tend to demand better institutions. We need to control for this measure of well-being so that the coefficients on the other exogenous variables will only reflect the direct impact of these factors on corruption, rather than effects operating indirectly through per capita income. However, given the fact that GDP per capita can be endogenous to institutions, its inclusion as a regressor needs further discussion, which we postpone to the next section.

The major concern with the results from OLS regressions, however, and in particular with respect to the effects of remittance flows, is that remittances could be endogenous to the presence of corruption, or more broadly to the quality of domestic economic institutions in general. It is very plausible that a higher level of corruption in a country could lead to higher emigration, which itself could lead to higher remittances. Therefore we need to isolate the causality from remittances to corruption from that operating in the reverse direction. To do so, we require an instrument for remittances. 


\section{B. The Coastal Area as an Instrument for Remittances}

To instrument properly for remittances we need a variable that is correlated with remittance flows but not correlated with our endogenous variable (corruption), except through included regressors. The coastal area of a country (defined as the ratio of the area within $100 \mathrm{KM}$ from a sea or an ocean to the total area of the country) appears to satisfy both criteria. As we will discuss below, this variable is likely to affect corruption primarily through its effects on included regressors such as per capita income. However, a higher coastal area is generally associated with a higher ratio of emigrants to the total population, which for obvious reasons leads to higher remittances on average. Accordingly, coastal area appears a priori to be an appropriate instrument for remittances. In a later section of the paper, we check for robustness and analyze the exclusion restriction in more detail; for now, we show and discuss the instrumental variable regressions.

Table 2 shows the first stage regression for both specifications (the legal variables and the religion variables respectively). We find that the impact of the coastal area on remittances is large and highly significant. The F statistic on the excluded instrument is equal to 7.59 in the first specification and 9.95 in the second, suggesting that our instruments do not suffer from significant weakness ${ }^{7}$. Columns (3) and (4) show the output from 2SLS second stage regressions. In the first specification we find a negative and significant coefficient at the $10 \%$ level, while in the second specification the significance level improves to $5 \%$. The coefficient

\footnotetext{
${ }^{7}$ Staiger and Stock (1997) set a benchmark of F statistic $=10$. Our F statistic is close to 10; however we do not rule out their weakness and we perform the Conditional Likelihood Ratio test proposed by Moreira (2003).
} 
is very similar across both specifications, however. The Conditional Likelihood Ratio test proposed by Moreira (2003), which is robust to weak instruments, shows that the coefficient on instrumented remittances is significant at the $5 \%$ level $^{8}$.

One problem with our instrument is that it may be correlated with institutional quality through channels other than remittance flows. In that case, coastal area would be a poor instrument, because the instrumented remittance variable would still be correlated with the disturbance term (unless these channels are explicitly accounted for in the regressions). Coastal area indeed tends to be correlated with variables that have been found to affect institutional quality through their effects on living standards, such as per capita real GDP itself and a variety of demographic variables that are highly correlated with per capita GDP. This is shown in Table 5 in Appendix A. While we did control for real GDP per capita, we did not control for the other demographic variables. This raises the question of whether instrumenting for remittance flows with coastal area while omitting these demographic variables from the regression may result in a biased estimate of the effects of remittance flows on institutional quality. ${ }^{9}$

\footnotetext{
${ }^{8}$ Both specifications are significant at the $1.5 \%$ level.

${ }^{9}$ It is worth noting, however, that if this is so, the coefficient on our instrumented remittance variable is likely to be biased in the direction opposite to that predicted by our model. This is because, aside from the remittance channel, our instrument is generally positively correlated with factors that are associated with better institutions ${ }^{9}$ : for example, our instrument is positively correlated with real GDP per capita, with the level of urbanization, and with the degree of commercial openness (as measured by the ratio of trade to GDP). All of these factors tend to be associated with better institutional quality, so their exclusion from the regression would tend to bias the coefficient on remittances in a positive direction. At the same time, our instrument is negatively correlated with age-dependency ratios and infant mortality, factors that are themselves generally negatively correlated with institutional quality, again inducing a positive bias.
} 
To address this potential bias we need to control for the effects of living standards on institutional quality. It is interesting to see that the coefficient on the instrumented remittance variable is negative and statistically significant as long as we control for either real GDP per capita itself or other variables that are correlated with it, such as dependency ratios, mortality rates and/or any combinations of such variables likely to affect institutional quality and to be affected by our instrument ${ }^{10}$. In columns (3) and (4) of Table 3, for example, we show the results from replacing per capita GDP by two demographic variables, dependence and urbanization. We can clearly see that these 2SLS regressions with the coastal area as instrument yield results similar to the ones in Table 2 columns (3) and (4).

But this procedure creates a second potential endogeneity problem. Like remittances themselves, measures of living standards such as per capita GDP are potentially endogenous with respect to institutional quality. Although we used the initial level of real GDP per capita in our estimation to mitigate this problem, since institutional quality is generally very persistent the endogeneity of GDP might still be an issue. Accordingly, we also instrument for real per capita GDP by the distance to the equator as in Treisman (2000). Columns (1) and (2) in Table 3 show the results of 2SLS estimation where we instrument for both remittances and real per capita GDP coastal area and distance to the equator as instruments. The coefficient on remittances remains negative and significant in these regressions.

Table 4 shows the result of the 2 SLS regressions of Table 2 when we vary the endogenous regressors to look at other indicators of institutional quality. We only show the specification

\footnotetext{
${ }^{10}$ We do not show these variations here.
} 
with the religion variables since the results obtained using the other specifications are very similar. It is interesting to see that remittances affect the three variables that are most related to corruption and government quality. We find a negative and significant coefficient on remittances (instrumented by the coastal area) in the regressions where the control of corruption, government effectiveness, and the rule of law measures are the dependent variables. As for regulatory quality and voice and accountability, they seem unaffected by remittances. This in itself is interesting since it suggests that only specific aspects of domestic institutional quality - those associated with the diversion of resources by the public sector - tend to be affected by the receipt of remittance flows.

\section{Robustness}

In this subsection we try to evaluate the robustness of our results by looking at some of the potential problems with our instrumental variable estimation. For an instrumental variable to be appropriate it must satisfy two conditions: relevance and exogeneity. The first can be verified empirically by looking at the correlation between the instrument and the endogenous regressor. In our case we showed that this correlation is strong and that in that respect our instrument is not particularly weak. As for the exogeneity condition, it deserves further discussion. A clear advantage of our instrument is that it is a geographical variable and therefore cannot be endogenous to institutions. This however does not guarantee exogeneity. Even if our instrument does not affect the dependent variable directly, it may do so indirectly through other channels that are not controlled for in our regression. In the rest of this section we first examine how our results are affected by controlling for a variety of other possible channels through which coastal area may affect institutions and then consider the use of an alternative instrument. 
The alternative channels through which coastal area may affect institutions include the following:

Openness: Our instrument is positively correlated (although weakly) with the ratio of trade to GDP in our data. This is to be expected through the effect of access to the coast on transportation costs. However, including the ratio of trade to GDP on the right hand side does not affect our results, as shown in the first column of Table 6. The coefficient on "trade to GDP" is positive but not significant.

Demographics: As shown in Table 5, our instrument is positively correlated with a measure of urbanization. This is also mentioned in Gallup, Sachs and Mellinger (1999). It is also negatively correlated with the dependency ratio and with infant mortality. As shown in column 2 of Table 6, however, controlling for these factors does not affect our results materially, as the coefficient on instrumented remittances remains negative and significant.

Continents: Another concern is that our instrument may be correlated with continent dummies. In fact, African countries on average have less shoreline than countries in other continents. Therefore one might suspect that our coefficient might be reflecting differences in institutions across continents that are not explained by our other regressors. However, as shown in the third column of Table 6 , controlling for continent dummies yields a coefficient with similar magnitude and significance level to our earlier results. ${ }^{11}$

\footnotetext{
${ }^{11}$ Aside from these variables, since our endogenous regressor (the ratio of remittances to GDP) is likely to be correlated with a measure of the ratio of the stock of migrants to the total original population at home, one might be concerned that our coefficient might reflect a negative impact of emigration on institutions, rather than of remittances themselves. However, it is not at all clear that the effect of emigration on domestic institutions
} 
To ensure that our results are robust we also consider an alternative instrument for remittances. Specifically, we use as our alternative instrument a measure of the distance between each country in our sample and the nearest country that is a large source of remittances. The implicit assumption is that, on average, the closer a country is to a major source of remittances the more likely it is that workers from that country will emigrate and send remittances back home. Note that this relationship is expected to hold mainly for developing countries, rather than for developed ones.

We know that the United States, followed by Western Europe and the Arab Gulf, are the largest sources of remittances in the world. Therefore for each country $\mathrm{x}$ this variable will take the value of the log of the distance between country $\mathrm{x}$ and the nearest of these remittance sources. Therefore for Latin American countries this variable will be the log of the distance between these countries and the US. The same is done for the Caribbean countries. As for Africa, we take the simple average of the distances from France and from Saudi Arabia. For Asia we use the distance to Saudi Arabia. Taking the distance of the European countries to France will, for obvious reasons, lead to a weak instrument as the distance is relatively small and received remittances to GDP in these countries are quite low. We can circumvent this

should be expected to be negative. Indeed, recent literature sees emigration as potentially beneficial to the home country. Specifically, authors such as Mountford (1997) and Beine et al. (2003), argue that the possibility of emigration raises the expected return on education at home, and thus is likely to increase investment in education, which has positive effects on productivity and growth. Beine et al. (2003) found a positive and highly significant effect of migration prospects on gross human capital formation. The increased stock of human capital in the home country may on average have a positive effect on institutions. Even the older literature on migration such as Grubel and Scott (1966) acknowledges that the short-term loss to the original country might be well offset in the long run due to spillovers and network effects. 
problem in three different ways: we can take the distance of the European countries to the United States instead, we can add a dummy for Europe as an additional instrument ${ }^{12}$, or we can exclude these countries from our sample. The three methods yield similar results. In

Table 7, we show the results from the first and second stage of the 2SLS regressions when we use the distance measure as an instrument and we exclude the European countries from our sample. Column (3) shows a negative and significant coefficient on remittances.

Furthermore the coefficient is comparable in magnitude to the one obtained from using the coastal area. Column (4) shows a negative yet non-significant coefficient when we use the religion variables as regressors. In Table 8, we show that when we use the United States as the main remitter for the European countries we obtain similar results. Note that our instrument is correlated with the distance to the equator for obvious reasons. In fact the correlation in our sample is around -0.56 . This is the reason why we control for the distance to the equator in our regressions.

\section{Conclusions}

We conclude that despite their nature as household-to-household private income transfers, remittance inflows may have adverse effects on domestic institutional quality - specifically, on the quality of domestic governance - that are similar to those of large resource flows. In our analytical model, this effect arises because when households receive remittances, the government finds it less costly to free ride on the households and their emigrant relatives and divert resources for its own purposes. In other words, because access to remittance income

\footnotetext{
12 This option might not be appropriate since this dummy might affect directly institutions even after controlling for GDP and other religious and legal variables.
} 
makes government corruption less costly for domestic households to bear, the government engages in more corruption. Remittances, by acting as a buffer between the government and its citizens, give rise to a moral hazard problem; these flows allow households to purchase the public good rather than rely solely on the government to provide that good, which reduces the household's incentive to hold the government accountable. The government can then free ride and appropriate more resources for its own purposes, rather than channel these resources to the provision of public services.

Our empirical results are strongly supportive of this proposition. Using standard specifications, and addressing issues of endogeneity and robustness, we consistently find a negative and statistically significant partial effect of remittance inflows on institutional quality.

One implication is that, while remittance inflows remain welfare-enhancing for the representative remittance-receiving household, the increase in household welfare is reduced by corruption, and the net increase in household welfare is lower the larger the government's temptation to steal (i.e., the larger the value of $\beta$ in the government's objective function). This suggests that IFI support for measures to facilitate remittance flows should be conditioned on government accountability. Otherwise the gains from such measures may accrue to parties other than those for whom they are intended.

Another implication concerns the relationship between remittances and economic growth. There is a fairly recent and growing empirical literature that attempts to measure the impact of remittances on economic growth. Overall, this literature fails to find a robust positive 
effect of worker remittances on growth. One possible reason for such a finding, among others, is the presence of several possible mechanisms through which remittances may affect growth, some of which identify a positive effect while others a negative one.

On the positive side, remittances may increase investment, facilitate human capital formation, enhance total factor productivity (TFP), and may have a favorable effect on the financial system, all of which potentially contribute positively to economic growth (see IMF 2005), World Bank 2006). However, remittances may also hamper economic growth through a Dutch Disease effect see for example, Acosta et al. 2007), and Montiel 2006), and by reducing labor supply and increasing investment risk (Chami et al. 2003).

This paper identifies a new channel through which remittances can affect economic growth. It is a fairly established empirical finding that better institutional quality enhances economic growth. ${ }^{13}$ Therefore, by worsening the quality of institutions in the recipient country, remittances can adversely affect growth. This channel has been missing from the empirical literature. Our results suggest that future empirical work on the relationship between remittances and growth needs to account for it.

\footnotetext{
${ }^{13}$ See, for example, Hall and Jones (1999), Knack and Keefer (1999), Mauro (1995, 1998), Acemoglu et al. (2001), Easterly and Levine (2003), Dollar and Kraay (2003), and Rodrick et al. (2004), among others.
} 


\section{REFERENCES}

Acosta, P. A., E. Lartey, and F. Mandelman. 2007. "Remittances and the Dutch Disease." Federal Reserve Bank of Atlanta Working Paper, 2007-08.

Beine, M., F. Docquier, and H. Rapoport. 2003. "Brain Drain and Growth in LDCs: Winners and Losers.” IZA Discussion paper. IZA Bonn.

Chami, R., A. Barajas, T. Cosimano, C. Fullenkamp, M. Gapen, and P. Montiel. 2008. Forthcoming. "Macroeconomic Consequences of Remittances.” IMF Occasional Paper. Washington: International Monetary Fund.

Chami, R., T.F. Cosimano, and M.Gapen. 2006. "Beware of Emigrants Bearing Gifts: Optimal Fiscal and Monetary Policy in the Presence of Remittances.” IMF Working Papers 06/61. Washington: International Monetary Fund.

Chami, R., C. Fullenkamp, and S. Jahjah. 2003. "Are Immigrant Remittance Flows a Source of Capital for Development?" IMF Working Papers 03/189. Washington: International Monetary Fund.

Gallup, J. L., J. Sachs, J. and A. Mellinger. 1999. "Geography and Economic Development." World Bank Annual Conference on Economic Development.

Grubel, H. G., and A. Scott. 1966. “The International Flow of Human Capital.” American Economic Review, 56: 268-74. 
International Monetary Fund. 2005. World Economic Outlook, April 2005: Globalization and External Imbalances, World Economic and Financial Surveys. Washington.

La Porta, R., F. Lopez-de-Silanes, A. Shleifer, and R.W. Vishny. 1999. "The Quality of Government.” The Journal of Law, Economics and Organization, 15: 222-279.

Leite, C., and M. Weidmann. 1999. "Does Mother Nature Corrupt? Natural Resources, Corruption and Economic Growth.” IMF Working paper WP/99/85. Washington: International Monetary Fund.

Moreira, M. 2003. "A Conditional Likelihood Ratio Test for Structural Models." Econometrica, 71(4): 1027-1048.

Mountford, A. 1997. "Can a Brain Drain be Good for Growth in the Source Economy?" Journal of Development Economics, 53(2): 287-303.

Orozco, M., and M. Lapointe. 2003. "Mexican Hometown Associations and Their Development Opportunities.” Inter-American Dialogue Research Paper Series, September.

Poterba, J. M., and J. J. Rotemberg. 1990. "Inflation and Taxation with Optimizing Governments." Journal of Money, Credit \& Banking, 22: 1-18. 
Roth, G. 1987. The Private Provision of Public Services in Developing Countries. New York: Oxford University Press for the World Bank.

Sala-i-Martin, X., and A. Subramanian. 2003. "Addressing the Natural Resource Curse: An Illustration from Nigeria.” IMF Working Paper WP/03/139. Washington: International Monetary Fund.

Staiger, D., and J. Stock. 1997. "Instrumental Variables Regression with Weak Instruments," Econometrica, 65(3): 557-586.

Treisman, Daniel. 2000. “The Causes of Corruption: A Cross-National Study.” Journal of Public Economics, 76: 399-457.

World Bank. 2006. Global Economic Prospects: Economic Implications of Remittances and Migration. Washington: The World Bank. 